ISSN 2411-4758 (Print) 2518-1602 (Online)

Native word in ethnocultural dimension, Drohobych, Posvit, 2021, pp. 98-111.

DOI: https://doi.org/10.24919/2411-4758.2021.214062

УДК $81 ' 371$

\title{
КОНЦЕПТ НАЦІЯ КРІЗЬ ІСТОРИЧНУ ПРИЗМУ УКРАЇНСЬКОЇ ПОЛІТИЧнОї дУМКИ
}

\section{Ярослав ЯРЕМКО,}

доктор філологічних наук, професор кафедри украӥнської мови, Дрогобиџький державний педагогічний університет імені Івана Франка (Україна, Дрогобич) уаremkojar@ukr.net

ORCID: http://orcid.org/0000-0002-8202-4107

Research ID: AAK-6199-2020 http://www.researcherid.com/rid/AAK-6199-2020

\section{Наталія ЛУЖЕЦЬКА,}

кандидат філологічних наук, дочент кафедри практики англійської мови, Дрогобицький державний педагогічний університет імені Івана Франка (Україна, Дрогобич) natalialuzhetska@gmail.com

ORCID: http://orcid.org/0000-0003-2414-6285

Research ID: AAD-4193-2019 http://www.researcherid.com/rid/AAD-4193-2019

Статтю подано до редколегіï/The article is submitted to the editorial board:

12.10.2020.

Статтю опубліковано/The article is published: 22.02 .2021$.

У статті висвітлено еволюиію семантики концепту нація як одного із вузлових компонентів політичної сфери. Шляхом когнітивно-дискурсного підходу окреслено смислове наповнення досліджуваного концепту у нерозривному зв'язку з історичним становленням украӥнської політичної думки. Власне лінгвокогнітологічний аналіз, опертий на міждисциплінарний фактичний матеріал, уможливив простежити багатогранність і динамічність концептуального поняття, його закономірну семантичну аморфність, зумовлену перманентним прочесом націєтворення.

Ключові слова: конщепт, нація, політична сфера, украйнський політичний дискурс. 
CONCEPT NATION IN HISTORICAL DEVELOPMENT OF THE UKRAINIAN POLITICAL THOUGHT

\section{Yaroslav YAREMKO,}

Doctor in Philology, Professor, Ukrainian Language Department, Drohobych Ivan Franko State Pedagogical University (Ukraine, Drohobych)yaremkoyar@ukr.net

\section{Natalia LUZHETSKA,}

Ph. D. in Philology, Associate Professor, English Practice Department, Drohobych Ivan Franko State Pedagogical University (Ukraine, Drohobych)natalialuzhetska@gmail.com

The article aims at performing linguistic and cognitive analysis of the concept nation in the historical establishment of the Ukrainian political thought.

The study represents the evolution of the concept semantics as one of the crucial components in the political sphere. It points out the tight connection between the meaning of the concept and the historical establishment of the Ukrainian political thought by means of cognitive and discursive approach. Linguocognitological analysis based on interdisciplinary phonetic material enabled to trace the multidimensional and dynamic character of the conceptual notion, its natural semantic amorphousness. The political features of the researched phenomena defines its character, while the process of nation creation is permanent. Thus, defining of the concept nation is always in progress.

Observation of the semantic evolution of the concept ethnos into the concept nation makes possible to realize the mechanism of the development of ethnos into nation - as "a way to ourselves", to our statehood.

Key words: concept, nation, political sphere, Ukrainian political discourse.

Постановка проблеми. Етнологи, культурологи й політологи сходяться в думці, що самореалізація етносу як суб'єкта історії можлива тільки в умовах політичної незалежності. Ї̈і гарантом виступає самостійна держава. Лише в цій держсаві - «своїй хаті» (Т. Шевченко) - людина може бути вільною (політично, економічно, ментально, культурно, мовно тощо) й може зреалізувати своє право на демократичні свободи. Тож названі концепти були і є одними 3 екзистенційно найважливіших для будь-якої національної спільноти. Простеживши семантичну еволюцію концепту етнос у концепт нація, ми усвідомимо механізм перетворення етносу в наиію - як дорогу «до себе», до власної державності.

Характеристика цих вузлових концептуальних понять - взаємопов'язаних і взаємозумовлених - потребує лінгвокогнітологічної оптики. Невипадково в сучасних лінгвістичних студіях помітно зростає питома вага 
когнітивістських досліджень, що опираються на міждисциплінарні принципи й розкривають взаємозв'язок національної культури - свідомості мови (Ф. Бацевич, В. Жайворонок, С. Срмоленко, Ю. Карпенко, Р. Кісь, В. Кононенко, О. Селіванова, М. Скаб, М. Федурко та ін.).

Мета нашої статті - лінгвокогнітологічний аналіз концепту нація в історичній проєкції на становлення української політичної думки.

Виклад основного матеріалу. У характеристиці феномену нація існує досить широкий спектр думок. Такий різнобій можна пояснити нетотожністю методологічних підходів до тлумачення цього поняття, його «прив’язаністю» до світоглядно різної політико-ідеологічної системи координат, складністю самого процесу націєтворення тощо. У типології визначень простежуються два різновиди: генетичний та структурний. Генетичні визначення нації грунтуються на таких чинниках, як спільність Духу, крові, а навіть раси (Основи політичної науки, 1997, с. 293). «Інші висували на перше місце волю, спільну психіку, єдину культуру, характер» (Основи політичної науки, 1997, с. 293). У цьому контексті показовим є трактування В. Антоновича, який визначальним критерієм нації вважав особливості характеру, зумовлені як природними чинниками, так і культурно-історичними. «За національність треба вважати суму таких прикмет, якими одна група людності відрізняється від цілого ряду інших груп, - підкреслював В. Антонович. - Прикмети бувають двох родів: одні природжені людям, спадкові, що залежать від складу раси, від впливу природи місцевої; їх можна знайти стежкою антропологічною, дослідом з анатомії та фізіології чоловіка. Другі прикмети здобуваються вихованням і залежать від вишини розвитку культури та від минулого життя народу, себто від його iсторії. Сума таких прикмет виявляє нам етнографічну індивідуальність, окрему національність [...]. Нація - група людей рідних і близьких (виділення наше - Я. Я., Н. Л.) між собою натурою, хистом, вдачею, дотепом, вдатністю, темпераментом. В оцій близькості і ріднині треба спостерігати дві речі: - одну - ті осібності та відміни, якими сама природа наділила людей, з якими чоловік починає життя своє, як з природженим, зі своїм власним; - другу - се ті осібності, що з'явились і виросли на грунті перших не самі по собі, а вироблено їх історією нації, їі культурою й історичним вихованням. Вони більш чи менш бувають оригінальні і залежать від того: чи щасливо, чи безталанно переходила історія нації» (Антонович, 1992, с. 4). У семній організації глибинного визначення політоніма нація звернемо увагу на стрижневі семи «близькості» і «ріднини», які пов'язані з етимологією латинського слова natio «народження, походження, рід; народ, нація» (ЕСУМ, IV, с. 53). Семантичний зв'язок із первинним значенням інтернаціоналізму паtio простежується в англійській та в усіх 
романських мовах, де корінь цього слова пов'язаний із народженням: якот у лексемах natio і native «рідний» (КОПС, с. 434).

Структурне визначення нащіï полягає у переліку ознак, які характеризують суть цього феномена. Однак у межах структурного різновиду різнобій тлумачень теж є очевидним. У радянський період із зрозумілих причин акцентувалися матеріалістичні складники цього поняття. Так, «Философский словарь» (1986) зазначає: «Нації притаманна передусім спільність матеріальних умов життя: території та економічного життя; спільність мови, відомих рис національного характеру, які проявляються у національній своєрідності їі культури» (ФС, с. 311).

Неважко помітити, що між генетичним та структурним підходами у визначеннях терміна нація межа аморфна, розмита. Тож відношення між ними $є$ не контрарними, протиставними, а комплементарними, взаємодоповнювальними. Синтетичний підхід до тлумачення цього політоніма простежуємо в СУМі, де зафіксовано: «Нація - конкретно-історична форма спільності людей, об'єднаних єдиною мовою і територією, глибокими внутрішніми економічними зв'язками, певними рисами культури і характеру» (СУМ, V, с. 233).

У терміносистемі сучасної політології семантичне наповнення політоніма нація помітно еволюціонувало, охопивши етнічні, політичні, духовні, психологічні ознаки: «Нація - історична соціоетнічна, політична, духовна спільнота людей з певною психологією, самосвідомістю, спільною територією, економічним життям, культурою, мовою» (Політологія, 2001, с. 397).

Сучасна західна концепція нації грунтується на найважливішій ознаці - національній державі на певній території або змаганні до неї. Поширеним у західній політології є погляд на націю як «сукупність людей, що має власну назву, свою історичну територію, спільні міфи та історичну пам'ять, спільну масову, громадську культуру, спільну економіку і єдині юридичні права та обов'язки для всіх членів» (Сміт, 1994, с. 23). Названі вище структурні ознаки, а також мова, походження, ментальність, національний характер є синтезом ідентифікувальних (ототожнення себе 3 членами свого етносу) та диференційних (відокремлення від інших етносів) ознак і формують основу етнічної ідентичності (лаm. identicus однаковий, тотожний ). Як бачимо, етнічна ідентичність опирається на два складники: 1) когнітивний (знання про свій етнос, його прикмети, історію, стосунки з іншими етносами тощо - самопізнання є передумовою і компонентом ідентифікації та знання про інші етноси, насамперед ті, 3 якими етнос більше чи менше контактує) та 2) емоційно-аксіологічний (ставлення до свого етносу та своєї належності до нього, бажання зробити свій внесок у його поступ, відданість йому, етнічна солідарність тощо) 
(Радевич-Винницький, 2013, с. 223). Кристалізація власне етнічної ідентичності є першим етапом у становленні нації, надаючи їй етнографічного змісту. Етнічне самоусвідомлення $\epsilon$ прерогативою культурної еліти. Своєю різнобічною культурно-просвітянською діяльністю (вивченням фольклору, мови, історії, звичаїв і вірувань, укладанням словників, виробленням загальноетнічної культури) вона закладає культурні підвалини націєтворення.

На початковому етапі становлення наиії простежуємо взаємодію концепту нація 3 концептом культура, а точніше - iз іії стрижневими компонентами історією та мовою. Об'єднує ці поняття те, що вони виступають найпотужнішим джерелом формування національної ідентичності, вагомим консолідаційним, націєтвірним чинником, без якого важко уявити повнокровне життя національного організму. Підкреслюючи екзистенційну значущість мови та історії для буття нації, політологи часто вдаються до використання метафоричного переосмислення соматичних назв (серие, нерв): «Ніщо так не мобілізує націю, як культура. Існували нащії і без держави - як-от довший час італійці, поляки, німці чи, зрештою, українці. Але їх єднала спільна культура. А серед тієї культури найчутливішими $\epsilon$ історія та мова. Вони - нерв, що творить зв'язок між минулим i сучасним, надає сенс і гідність нашому життю. Зачепіть цей нерв, натисніть на нього і закричите від болю» (Я. Грицак).

Концепт нація, крім етнографічного змісту, пов'язаного з етнічною ідентичністю, має і політичний зміст, що опирається на громадянську (політичну) ідентичність. Громадянська ідентичність є результатом політичної самоорганізації достатньо розвиненої етноспільности. Цей вид ідентичності формується на основі усвідомлення індивідом своєї належності до спільноти громадян конкретної держави. Адже саме у своїй державі може всебічно реалізуватися концептуальна особистість - чи індивід, чи нація («колективний індивід», «збірна особистість»). Саме держава виступає гарантом політичної незалежності, до якої прагне на другому етапі націєтворення політична спільнота. У таких суспільно-політичних умовах процеси націєтворення й державотворення $€$ взаємозумовленими - в надрах одного зароджується інший. Тож на цьому етапі концепт наиія перетинається з концептом держава, унаслідок чого його сематичне поле набуває «прирощень» смислу, нових конотативних відтінків, асоціативно-оцінних рядів.

Два різновиди ідентичності - етнічна та громадянська - як відображення двох етапів націєтворення дали підстави запровадити терміносполуки етнічна начія та політична начія, які, на думку відомого вченого А. Свідзинського, є «дуже невдалими термінами. «Етнічна нація» ще да- 
леко не нація, це в кращому разі етнос, в гіршому - етнічний субстрат. «Політична націяя - це взагалі екзотичне утворення, нестійке в історичному часі. Випадки суто політичного об'єднання різних етносів мають маргінальний характер (Канада нині багато потерпає від міжетнічних суперечностей, у США після переходу від політики «плавильного казана» до політики культурного плюралізму такі суперечності неминуче будуть зростати)» (Свідзинський, 2009, с. 278 - 279).

В українському політичному дискурсі тлумачення поняття «політична нація» часто здійснюється через аксіологічні параметри, у яких знівельовано етнічний компонент, як-от: «Безсумнівно, нам і надалі необхідно будувати політичну націю не на етнічній основі» (О. Дергачов). Імплікатура «не на етнічній основі» набуває демоліберальної конкретики у мовленні іншого політолога, який «виступив з черговим прожектом консолідації України на основі так званого мультикультуралізму, коли в країні немає жодної об'єднавчої культури, титульної нації. А є щось подібне до етнонаціонального Ноєва ковчега, де «всякої тварі по парі», де суспільна мозаїка різних культур, де жодна культура не має пріоритету, а поняття «корінний народ» втрачає будь-який сенс. Відповідно, країна перетворюється на абстрактну територію, а нація - на «певне зборище індивідів, позбавлених етнічного, культурного й історичного грунту» (І. Лосєв).

У посттоталітарному комунікативно-інформаційному просторі, де комуністичну глобалізацію змінила тотальна глобалізація лібералізму, виникає загроза ідентичностям (етнічній, національній, мовній, культурній, релігійній) корінного населення (титульної нації). Це змушені були визнати лідери європейських держав (Франції, Британії, Німеччини), які публічно, на підставі досвіду своїх країн, заявили, що політика мультикультуралізму зазнала краху.

Нівеляційні хвилі глобалізації повсюдно проникають і в українську політичну дійсність. Мало того - їх вплив часто штучно посилюється тими, хто «волів би утворити під назвою української нації дефектну «чистополітичну» націю»), а Українську державу зробити якимось космополітичним об’єднанням. Вони не від того, щоб побудувати незалежну Україну, але без домінуючої української культури. Це так само шкідливо, як і протилежна крайність, про яку писав Донцов. Отже, за терміном nолітична нація стоїть не просто дефектне уявлення про націю, а й шкідлива, ворожа для української державності вигадка. Українська нація має бути етнополітичною єдністю, як і всяка повноцінна нація» (Свідзинський, 2009 , с. $279-280$ ).

Трактування нації як діалектичного, гармонійного зв’язку «громадянського» й «етнічного» простежуємо й у концепції відомого політолога 
Р. Шпорлюка, котрий на основі свого закордонного досвіду (зокрема комунікативного) стверджує: усі нації є водночас і «громадянськими» й «етнічними»; кожна нація має певний мовно-культурний стрижень, певне ядро, хоч би якою «надетнічною спільнотою» вона себе проголошувала (як СРСР) і хоч би які (як США) «позаетнічні політичні концепції громадянства» сповідувала. Навіть у найліберальніших багатомовних-багатокультурних державах котрась мова й культура завжди виявляється трішки рівнішою від інших» (див.: Рябчук, 2003, с. 292).

Менталітет ліберальних американців, що проявляється передусім у системі цінностей, характері, вчинках, комунікативній поведінці, сконденсовано характеризує їхня ж фразема: «Бог допомагає тому, хто допомагає собі сам». А оскільки вони й не менші демократи, то у мовній сфері цю допомогу собі розуміють так: «Дуже небезпечно дозволяти, аби двомовність і надалі поширювалася. Ми повинні наполягати на тому, що англійська є нашою спільною мовою... Це те, що об'єднує нас». Так сформував стрижень державної мовної політики спікер палати представників США Ньют Гінгріч після референдуму у Квебеку, результати якого засвідчили про реальну небезпеку відокремлення цієї франкомовної провінції від високорозвиненої Канади. Зауважимо, що у США «двомовність уведено тільки в освітні програми 3 метою адаптації дітей іммігрантів, які навчаються за двомовними програмами у середньому не більше трьох років» (Масенко, 2004, с. 16). Треба визнати, що за масштабами двомовності в Україні демократії незрівнянно більше, особливо у світлі ухваленого 3 липня 2012 р. закону «Про засади державної мовної політики».

$\mathrm{Te}$, що цей заполітизований «мовний закон» було ухвалено з порушенням Конституції України, норм регламенту і процедури розгляду, виразно ілюструє: розвиток концепту мова надалі не відповідає статусу мови, що проголошена державною. «Демократичні» маніпуляції мовою в сучасному культурно-інформаційному просторі лише підтверджують невтішне передбачення I. Дзюби, котрий більш як за десятиліття до цього застерігав: «Немає сумніву: за рахунок капітуляції в мовному питанні, за рахунок української мови намагатимуться компенсувати політичні та економічні прорахунки, соціальні біди. Українською мовою торгуватимуть у передвиборчій метушні. На українській мові як емблемі українства окошиться невдоволення багатьох існуючим станом речей. I те, що не встигли доконати царський урядник, московський піп і більшовицький комісар, докінчать різні шаромижники «общерусскости», компрачікоси «комуністичної ідеї» та коновали «лібералізму» (Дзюба, 2005, с. 40).

Семантична розмитість терміна начія створює підгрунтя для ототожнення політонімів «народ Украӥни» і «украӥнська політична наиія». 
Ще не так давно офіційна радянська пропаганда активно маніпулювала формулами «народи Украӥни», «Украӥна - багатонаціональна республіка». «Сенс таких формул зрозумілий - поставити під сумнів право українського народу вирішувати долю своєї Вітчизни. Україна - не багатонаціональна держава, як, скажімо, Югославія, Індія чи Індонезія, а держава з багатонаціональним складом населення, як більшість європейських держав. А це принципово різні речі, - наголошує Іван Дзюба. - Такий висновок треба зробити не для того, щоб ігнорувати національні меншості та групи в Україні, а для того, щоб заперечити антиукраїнські політичні спекуляції на цьому питанні, підкопи під суверенність українського народу» (Дзюба, 1997, с. 12 - 13). Якщо поглиблювати семантичне наповнення політоніма «народ України», то це варто зробити через зіставлення з іншим політонімом - «украӥнський народ». Те, що відрізнятиме ці також часто ототожнювані терміни, буде суттю кожного із них. Сучасна українська політологічна думка стверджує, що «при правомірності застосування кожного з них для означення одного й того самого феномена (сукупності людей, що належать до різних етносів, але становлять єдину націю) перше фіксує увагу на населенні території Україна, а друга - на українській нації як поліетнічній спільності людей, які мають свою державу, усвідомлюють свою національну та громадянську належність» (Політологія, 2001, с. 198). Як бачимо, слова, що сприймаються як синоніми у філології, не є такими у політології: їхній зміст визначають юридичні закони, а точніше - конкрентна політична практика, характерна для певної етноспільноти (державної, декларативно державної чи бездержавної).

Стрижневим компонентом концепту нація є поняття національної iдеï. Навколо цього поняття і формується нація. А втім, наиіональну ідею в українському політичному та культурному дискурсі можна помітити задовго до того, як виник сам політичний термін. Національна ідея - категорія історична. На різних етапах націєтворення вона набуває різного змісту. В українській суспільно-політичній думці, коли Україна тривалий час перебувала у складі інших держав імперського типу, провідною ідеєю була ідея соборності українських земель. Справжнім символом національного соборництва був Михайло Грушевський, котрий у листі від 6 грудня 1919 р. до канадських українців наголошував: «Нарід наш висловив свою волю, щоб Україна була одна, Східна і Західна, Наддніпрянська і Наддністрянська, оден край і оден народ, одно тіло й душа (виділення наше - Я. Я., Н. Л.) і нема чого копирсатися в другорядних відмінах сих двох частин нашої вітчизни, заподіяних неприхильними обставинами нашої історії. Треба підносити і скріпляти все те, що їх єднає та в'яже, а не 
те, що їх ріжнить та ділить». Та втілення цієї великої ідеї потребує від людини, від етнічної спільноти усвідомлення своєї належності до нації, спільності історичної долі, культури, менталітету, тобто національної самосвідомості. Тож невтомний речник цієї ідеї - соборності українських земель - Іван Франко висуває за своєю суттю національно-когнітивістське гасло «чути себе україниями», наголошуючи, що національна згуртованість потребує внутрішньої єдності і розуміння: «Ми мусимо навчитися чути себе украӥнцями - не галицькими, не буковинськими українцями, а українцями без офіціальних кордонів. Ми повинні - всі без виїмка - поперед усього пізнати ту свою Україну... А головно, щоб ми розуміли (виділення І.Франка) всі прояви ії життя, щоб почували себе справді, практично частиною його» (Франко, 1986, с. 405).

Національною ідеєю може бути й збереження культурної ідентичності, значущість якої зростає особливо в умовах бездержавності. Прихильниками культурницької праці серед населення були представники народницького (народовського) руху, названі в українському політичному дискурсі народовці-хлопомани. Вони наголошували на своєрідності психіки українського народу, його побуту й господарства, підкреслювали індивідуалізм українського селянства. А ще, за словами І. Франка, казали «любити щонайбільше язик народу (виділення I. Франка), а не сам народ» (Франко, 1986, с. 220). При цьому культурницька праця розумілась українькими народниками як національна.

Виникає закономірне питання: чи може «культурництво» сприяти перетворенню етносу в націю? Даючи політичну оцінку явищу народництва, С. Маланюк супроводжує його семантично зниженою ремаркою «т.зв.» і характерними асоціативними означеннями «зловісне, чисто-інтелігентське»: «I справді, вже від другої половини XIX ст. наше селянство виразно стає головним єством наџиï і навіть їі репрезентантом. Звідсіль приходить таке зловісне потім у своїх наслідках і залишках (щоправда, в ідеї - чисто-інтелігентське) т. зв. народництво, що таку трагічну антидержавну ролю відограло в психіці проводарів Відродження ХХ ст.» (Маланюк, 1992, с. 60).

Коли ж етнос починає усвідомлювати необхідність створення власної держави, тоді поняття національної ідеї набуває нового змісту. Ним стає боротьба за державну незалежність. Власне, державно-політичні вимоги сприяють трансформації етносу в націю як явище соціально-політичне. Без державного інстинкту цього не відбудеться, оскільки використовувати «для домашнього вжитку» свою мову та свої пісні можна й у чужій державі. А в результаті не відбувається еволюції концепту етнос у концепт нація. 
Тож навіть у затяжні періоди бездержавності в Україні завжди були справді концептуальні особистості пасіонарного типу, чий спосіб мислення й поведінки можна передати аксіологічно містким словосполученням лицарі абсурду. Персоніфікованим втіленням цього метафоричного вислову є його автор Олена Теліга - пасіонарія свого часу. Сучасна політологія трактує пасіонарність як цілеспрямовану, стоїчну діяльність людини (часто у несприятливих умовах) в ім'я суспільно значущої мети, заради досягнення якої нерідко доводиться жертвувати і життям інших людей, і своїм власним. Свою візію пасіонарності Олена Теліга доносить до адресата через протиставлення двох типів політичної свідомості: за їі словами, лицарів абсурду, - 3 одного боку, партачів жит$m я,-з$ іншого: «Тому були у нас лицарі абсурду і власне така маса, що ідею цих лицарів обертала в абсурд своєю байдужістю до неї і чемністю та терпимістю супроти ворогів. Тому-то тими лищарями абсурду були у нас не лише герої Базару, Крут, Білас і Данилишин, а й такі постаті, як Шевченко, Міхновський, Олена Пчілка, Франко і Леся Українка, сучасники яких, - і то не темна маса, а найближче оточення, інтелігенти або не розуміли цілої їх величі, або - що було далеко ще гірше - навіть розуміли i, захоплюючися ними, не могли позбутися своєї льокайської психіки» (Теліга, 1992, с. 106). А далі О. Теліга когнітивно проникливо розкриває подвійні стандарти сервільної, пристосовницької поведінки тих, кого вона називає партачами життя: «Завдяки ій [льокайській психіці] вони боялися одвертою підтримкою цих героїчних і адорованих ними одиниць викликати недовір'я і охолодження до себе свого зненавидженого «пана». I та порода хитрих льокаїв, що широко розчиняла двері перед героєм і била йому земні поклони, коли того не бачили пани, та не пізнавала його і гнала в шию, коли хтось 3 тих панів був присутній, - була безперечно більш огидна і більш небезпечна, аніж виразно окреслені, тупі раби, що справді не відчували, з ким мають до діла, і незалежно від ситуації, дерев'яно, але щиро виконували свій обов'язок не звертати уваги, гнати» (Теліга, 1992, 106-107).

Такий спосіб політичної поведінки, у якій проявлявся «параліч політичної волі і думки», а як наслідок - втеча від політики, національне каліцтво, С. Маланюк дещо пізніше (у «Книзі спостережень», 1959 р.) назве малоросійством, наголошуючи на внутрішньому, ментальному характері цієї хвороби, насамперед інтелігенції: «У нас фатально закорінилося майже переконання, що малорос - то, мовляв, неосвічений, примітивний, недорозвинений українець без національної свідомості... Вистачить, мовляв, його просвітити, переконати й усвідомити - і справа полагоджена... У нас малоросійство було завжди хворобою не лише півінтелігентською, 
але - й передовсім - інтелігентською, отже поражало верству, що мала виконувати ролю мозкового центру нації» (Маланюк, 2012, с. 16). Цю історичну місію довелося виконувати лицарям абсурду. Своїм далекосяжним державницьким баченням, жертовністю зусиль, духовним стоїцизмом вони надали національній ідеї нового, політичного змісту, серцевина якого - змагання до повної національної незалежності.

Такий державотворчий смисл, закладений у концепті національна iдея, не усвідомлювало багато сучасників Лесі Українки з «інтелігентської верстви». Наџіональна ідея, що була лейтмотивом життя і творчості поетеси, прихильникам «здорового глузду» видавалася «дивною ідеєю», «жіночою химерною примхою». Оскільки складовою концептуального аналізу є також опертя на публіцистичний чи художній текст, «знаходження в ньому тих часом недостатньо помітних, а в сутності своїй визначальних показників смислу» (Кононенко, 2004, с. 19), наведемо спогади сучасників Лесі Українки як культурного документа доби і своєрідного джерела для «дешифрування» висловленого, а точніше - для виведення імпліцитного текстового смислу. Королів-Старий згадував, «як чужа вона [Леся Українка] була всім і яким незрозумілим був їі шлях. Вона їм не подобалася. Не гарна, зле вдягнена, без смаку, і з дивними ідеями: в той час, коли всі хотіли лише трохи освіти для народу, вона висловлювала таку жіночу химерну примху - боротьба за цей нарід і його цілковите визволення» (Теліга, 1992, с. 115). За висловами тексту незрозумілим був ї̈ илях; дивні ідё; жіноча химерна примха відтворюється імплікація з прихованим соціальним смислом: «бо це політичний і моральний максималізм, який був загрозою для інтелігентського аполітичного життя». А читач із цього мікротексту виведе свою імплікацію: «якщо так пасіонарність Лесі Українки сприймали «свої», то на яке розуміння можна було сподіватися від «чужих»? За утвердження «ідеалу національної самостійності в усякім погляді, культурнім і політичнім», «поза межами можливого» виступав тоді хіба що Іван Франко (Франко, 1986, с. 285).

1991 р. цей ідеал набув реального втілення - Україна проголосила незалежність, а відтак на новому історичному етапі еволюціонувала національна ідея. У сучасній політологічній думці існують різні визначення національної iдё̈, оскільки немає тотожних поглядів на національні інтереси, мету й пріоритети держави. Однак базовим семантичним компонентом у нинішньому трактуванні поняття національна ідея є сема «державотворення». Якщо в період бездержавності головним змістом украӥнської національної ідеї було здобуття незалежності, то сьогодні, на думку політологів, - це «розбудова засад вже здобутої державності - політичних, соціальних, економічних, духовних. Тобто йдеться про створення модерної 
цивілізованої держави (а не бюрократично-поліцейського монстра, небезпека чого нині гостро відчувається) - національно-орієнтованої, правової, політично та економічно самодостатньої. І цей зміст національної ідеїдержсавотворення - стає основою ідеології в сучасному українському суспільстві» (Політологія, 2001, 195).

У наведеному вище контексті впадає в око ряд прикметникових означень термінологічного характеру модерна, цивілізована, демократична, правова, пов'язаних із характеристикою держави, яку потрібно створити. Найточнішу, найвиразнішу оцінку реалії передають ті означення, семантику яких підсилюють супровідні прислівники: національно орієнтована, політично та економічно самодостатня. Виконуючи роль кваліфікаторів, такі аналітичні словосполучення відбивають національне розуміння держави. Мабуть, саме у такій державі може повністю самореалізуватися природа людини. Невипадково слова-епітети наповнені позитивно оцінним змістом.

Однак політичний дискурс має ту особливість, що він постійно стимулює семантичну динаміку епітетів. За цією мінливістю можна простежити, як умови політичного, економічного, культурного, духовного життя відбиваються в означуваності політичних реалій, як семантично відрізняється сприйняття політичного світу - декларованого й реального.

Про те, що зміст національної ідеї кінця XX - початку XXI ст. - державотворення - часто наповнюється далеко не державницьким змістом, засвідчує, наприклад, аналітична праця С. Марчука, де характеристику цього непростого процесу сконденсовано у заголовку книги: «П'ять років української трагедії» (1999р.). Не схильний до драматизації подій, автор використовує такі негативно-оцінні означальні словосполучення: тіньова економіка, функиіонування «паралельної влади», політичні олігархи, владно-економічні клани, депутатська недоторканість, приховані механізми впливу, корумпована державна бюрократія, «нові украӥниі», владний мундир, відсутність громадянського контролю тощо.

Звичайно, у політичній картині світу, яку створює той чи той автор, вимальовується як типове, колективне сприйняття політичної дійсності, так й індивідуальне. Суб'єктивні індивідуальні оцінки увиразнюють, оживляють словесне зображення політичної картини світу. Вони через незашорене, критичне думання автора актуалізують фонові знання адресата, змушують його погоджуватись чи не погоджуватись 3 висловленою думкою.

Висновки та перспективи подальшого дослідження. Різнобічний фактичний матеріал, дібраний для характеристики концепту нащія із текстів української наукової, публіцистичної та художньої літератури, мови засобів масової інформації, лексикографічних (етимологічних, тлу- 
мачних, перекладних) праць, відбиває багатогранність і динамічність аналізованого концепту, його певну семантичну аморфність. Це зумовлено полівимірною природою одного з вузлових понять сучасної політичної думки. Тож кристалізація концепту нація ніколи не завершується, оскільки перманентним є процес націєтворення.

Перспективи опрацювання лінгвонаціософської проблематики вбачаємо у поєднанні когнітивного та комунікативно-прагматичного підходів, що дасть змогу поглибити мовну концептуалізацію досліджуваної політичної сфери.

\section{Умовні скорочення лексикографічних джерел}

ЕСУМ - Етимологічний словник української мови. (1982 = 2012). Київ: Наукова думка. T. I - VII.

КОПС - Короткий Оксфордський політичний словник (2006). [Пер. з англ.; За ред. І. Макліна, А. Макмілана]. Київ: Основи.

ФС - Философский словарь (1986). [Под ред. И. Т. Фролова]. Москва: Политиздат, 1986.

СУМ - Словник украӥнської мови: В 11 т. (1970. - 1980). Київ: Наукова думка.

\section{СПИСОК ЛІТЕРАТУРИ}

Антонович, В. (1992). Три національні типи народності. Старожитності, № 3 .

Дзюба, І. (1997). Між культурою і політикою. Київ: Сфера.

Дзюба, І. (2005). Інтернаціоналізм чи русифікація? Київ: Вид. дім «Києво-Могилянська академія».

Кононенко, В. (2004). Концеепти українського дискурсу. Київ - Івано-Франківськ: Плай.

Маланюк, Є. (2012). Малоросійство. Малоросійство. Нариси з історї нашої культури [Серія «Бронебійна публіцистика»; За заг. ред. Лариси Івшиної]. Видання друге. Київ.

Масенко, Л. (2004). Мова і політика. Київ: Вид. дім «КМ Academia».

Основи політичної науки: Курс лекцій за ред. Б. Кухти. Ч. 2: Політичні процеси, системи та інститути. (1997). Львів: Кальварія.

Політологія [За заг. ред. І. С. Дзюби, К. М. Левківського]. (2002). Київ: Вища школа.

Радевич-Винницький, Я. (2013). Мовна складова національного буття: студії з украӥнської лінгвоначіологї. Київ - Дрогобич: Посвіт.

Свідзинський, А.В. (2009). Синергетична концепція культури. Луцьк: ВАТ «Волинська обласна друкарня».

Сміт, Н. (1994). Національна ідентичність. 3 англ. пер. П. Таращук. Київ: Ocнови.

Теліга, О. (1992) Партачі життя. Київ: Вид-во ім. О. Теліги. - Київ - Париж - Лондон - Торонто - Нью-Йорк - Сідней. 
Франко, І. (1986). Одвертий лист до га[лицької] української молодежі. Зібрання творів: У 50 т. Т. 45. Київ: Наукова думка, $401-409$.

Франко, І. (1986). Поза межами можливого. Зібрання творів: У 50 т. Т. 45. Київ: Наукова думка, 276 - 285.

Франко, І. (1986). [Промова на ювілеї М. П. Драгоманова] Зібрання творів: У 50 т. Т. 45 . Київ: Наукова думка, $220-227$.

\section{REFERENCES}

Antonovych, V. (1992). Try natsionalni typy narodnosti [Three national types of nationality]. Starozhytnosti - Antiquities, № 3. [in Ukrainian]

Dzyuba, I. (1997). Mizh kulturoyu i politykoyu [Between culture and politics]. Kyiv: Sfera. [in Ukrainian]

Dzyuba, I. (2005). Internatsionalizm chy rusyfikatsiya? [Internationalism or Russification?]. Kyiv: Ed. house «Kyevo-Mohylyanska akademiya». [in Ukrainian]

Kononenko, V. (2004). Kontsepty ukrayinskoho dyskursu [Concepts of Ukrainian discourse]. Kyiv - Ivano-Frankivsk: Play. [in Ukrainian]

Malanyuk, YE. (2012). Malorosiystvo. Malorosiystvo. Narysy z istoriyi nashoyi kul'tury [Little Russia. Little Russia. Essays on the history of our culture [Series "Armor-piercing journalism»; For the general ed. Larysa Ivshyna]. Second edition. Kyiv. [in Ukrainian]

Masenko, L. (2004). Mova i polityka [Language and politics]. Kyiv: Ed. house «KM Academia». [in Ukrainian]

Osnovy politychnoyi nauky: Kurs lektsiy za red. B. Kukhty. Ch. 2.: Politychni protsesy, systemy ta instytuty [Fundamentals of political science: Course of lectures edited by B. Kukhta. Part 2: Political processes, systems and institutions]. (1997). Lviv: Kalvariya. [in Ukrainian]

Politolohiya : za zah. red. I. S. Dzyuby, K. M. Levkivskoho [Political Science: for general. ed. I. S. Dzyuba, K. M. Levkivsky]. (2002). Kyiv: Vyshcha shkola. [in Ukrainian]

Radevych-Vynnytskyy, Y. A. (2013). Movna skladova natsionalnoho buttya: studiyi $z$ ukrayinkoyi linhvonatsiolohiyi [Linguistic component of national life: studies in Ukrainian linguo-sociology]. Kyiv - Drohobych: Posvit. [in Ukrainian]

Svidzynskyy, A. V. (2009). Synerhetychna kontseptsiya kultury [Synergetic culture concept]. Lutsk: VAT «Volynska oblasna drukarnya». [in Ukrainian]

Smit, N. (1994). Natsionalna identychnist. Z anhl. per. P. Tarashchuk [National identity. From English lane. P. Tarashchuk.]. Kyiv: Osnovy. [in Ukrainian]

Teliha, O. (1992) Partachi zhyttya [Spoilers of life]. Kyiv: O. Telihy Publishing House. Kyiv - Paryzh - London - Toronto - N'yu-York - Sidney. [in Ukrainian]

Franko, I. (1986). Odvertyy lyst do ha[lytskoyi] ukrayinskoyi molodezhi [An open letter to Galician Ukrainian youth.]. Zibrannya tvoriv: U 50 t. T. 45 - Collection of works: In 50 vols. Vol. 45. Kyiv: Naukova dumka, 401 - 409. [in Ukrainian]

Franko, I. (1986). Poza mezhamy mozhlyvoho [Beyond the possible]. Zibrannya tvoriv: U 50 t. T. 45 - Collection of works: In 50 vols. Vol. 45. Kyiv: Naukova dumka, 276 - 285. [in Ukrainian]

Franko, I. (1986). Promova na yuvileyi M. P. Drahomanova [Speech on the anniversary of M. P. Drahomanov]. Zibrannya tvoriv: U 50 t. T. 45 - Collection of works: In 50 vols. Vol. 45. Kyiv: Naukova dumka, 220 - 227. [in Ukrainian] 